DOI: $10.1515 / \mathrm{rpp}-2015-0070$

$\mathrm{PhD}$ in Pedagogical Sciences, Associate Professor, ANTONINA CHYCHUK

Bohdan Khmelnytskyi Cherkasy National University, Ukraine Address: 81 Shevchenko Blvd, Cherkasy, 18031, Ukraine

E-mail: tetyanna@ukr.net

\title{
THE SYSTEM OF TEACHER EDUCATION MANAGEMENT IN GREAT BRITAIN
}

\begin{abstract}
The system of teacher education management, namely, forms and principles of teacher education management according to the normative base (Education Reform Act (1988); Education Act (1992; 1993; 1996; 1997; 2002); School Standards and Framework Act (1998); Higher Education Act (2004), etc.), monitoring and participation of the public in its management have been analyzed. It has been proved that lately the democratization process in British education management has been combined with the increased attention of the state to monitoring, requirements to appropriate activity of educational establishments and trends seem to be forward education quality enhancing, democratization of evaluation, monitoring and information providing processes. Changes in education management in the historical context have been considered. The organizations participating in education management in Great Britain have been outlined. The data has been presented that enabled to distinguish similarities and differences in the functioning of the organizations participating in education management in Great Britain and ensure the existing of independent management authorities within them.
\end{abstract}

Key words: teacher education, management system, forms and principles of management, Great Britain.

\section{INTRODUCTION}

In the context of integration and globalization processes in the educational system of Ukraine the management of educational establishments is becoming extremely essential. The study of foreign experience in education management could be of help in this matter, in particular, British one.

The system of teaching and learning in preschool establishments, schools as well as the professional training of future teachers in Great Britain are characterized by the system of education management by both the government that adopt laws aimed at modernizing the training of teaching staff and local authorities (Кучай, 2014). It should be noted that normative documents of Great Britain include defined responsibilities of subjects in the educational system, established measures of responsibility for violation of educational rights that really contributes to the performance of educational management authorities (Шмакова, 2006).

THE AIM OF THE STUDY

The aim of the paper is to study the peculiarities in the system of teacher education management in Great Britain.

\section{THEORETICAL FRAMEWORK AND RESEARCH METHODS}

The analysis of the studied problems proves the considerable interest of domestic and foreign scholars in systems of pedagogical education, in particular, professional training of teaching staff (N. Avshenyuk, T. Kuchay, L. Pukhovska, Yu. Strunkina, 
K. Zyskin and others). Theoretical framework of the study include acts on education in Great Britain, namely, Education Reform Act (1988); Education Act (1992; 1993; 1996; 1997; 2002); School Standards and Framework Act (1998); Higher Education Act (2004) etc.

To achieve the set aim such methods as analysis, synthesis, generalization and systematization have been used.

\section{RESULTS}

In Great Britain children are admitted to preschools and primary schools under the School Standards and Framework Act (1998) and Education Acts (1992; 1993; 1996; 1997; 2002). Also the admission is to be registered in the statute book of the educational establishment (Шмакова, 2006).

While admitting to school it is obligatory to sign a contract on the partnership with the school and also parents' declaration that define the duties of the school and the parents according to Education Act (1997) (Education Act, 1997). Provided parents did not send their child to school, local authorities count it as a violation of rights and demand that the parents pay a fine according to legislation (Education Acts $(1996,1997,2002))$.

Education and Inspections Act is based on Education Act (1992) and includes the criteria for evaluating students' achievements, education quality, education content, teaching and learning methods, students' development and behaviour etc., namely, how schools train students for cooperation with each other in different life situations, working successfully in a group, active participation in everyday school life. The abovementioned criteria were revised and added to Education Act (1996).

In 5 years (1992-1997) primary and secondary schools were improved in response to a range of legislative initiatives. The main trend in such a reformation consisted in transferring the power of decision-making to local education authorities (schools and parents) with the right of the state to participate in the process.

According to Education Act (1993) children with special educational needs (mental or physical disorders) can attend schools with parental consent.

Under the Education and Inspections Act the inspection of state preschools and primary schools' performance is held once in five years (Education Act, 1996).

It should be mentioned that legislative acts have a great impact on higher education development, too. During the second half of XX century acts on reforming systems of teacher training were enacted, in particular, Initial Teacher Training: A Consultation Document (1983), In-service Teacher Training (1991), Teachers: Meeting the Challenge of Change (1998), where different aspects of teacher education are considered (Стрункина, 2012).

The main task of Education Reform Act (1988) is to consider enhancing of education level as a factor for economic development of Great Britain (The Education Reform Act, 1988).

Higher Education Act (2004) solves the financial problem of university education, trends in higher education accessibility through the introduction of multi-level teacher training (Five Year Strategy for Children and Learners, 2006). Such measures were taken: The Council for the Accreditation of Teacher education (CATE) (1984) was established to set standards for initial teacher training courses (the enhancement of centralization); Teacher Training Agency (TTA) published competences teachers are to acquire (1995); National College for Teaching and Leadership was established in 1990 aimed at monitoring educational process in higher educational establishments in Great Britain; Department for Education enacted The National Curriculum for Initial Teacher Training in 1997 and established Office for Standards in Education (Ofsted) ensuring its realization (Стрункина, 2012). 
We also consider it essential to review how education management underwent changes in the historical aspect.

In the first part of XIX century grammar schools provided advanced education and were subjected to special councils. In the middle of XX century teacher education was regulated by regional organizations of teacher training called teacher institutes that consisted of teacher colleges located on the relevant area and teacher departments of the nearest university. Curricula of educational establishments were based on the institute's optional recommendations (Зискин, 2002).

The researcher Yu. Strunkina indicates that main difficulties in teacher training in England during the 1960s were decentralization, the absence of connection between educational establishments' performance, common curriculum and requirements to teacher. The education content was subjected to criticism (Стрункина, 2012).

In 1960s the labour government demanded that local authorities subjected to Department for Education regulate the management of teacher training (Зискин, 2002). In 1960-1970s the power of teacher education management was transferred from regional to local authorities that established the trend in centralization of education system in general and considered to be one of the elements in developing education management, in particular, teacher education. Department for Education took charge of teacher education management and, unlike previous years, not only engaged in funding of educational establishments providing teacher education and defining needs for teaching workforce according to demographic situation but also issues connected with teacher education content and improvement of forms and methods for future teachers' training (Зискин, 2002). In 1984 teacher institutes were eliminated. Their function was now performed by The Council for the Accreditation of Teacher Education (Стрункина, 2012). So, from 1960 till 1980 education policy in Great Britain became rather centralized.

In 1998 the list of common standards for teacher training was published. The trend in developing teacher education during 1990s of XX century is characterized by both democratization of management system and education centralization according to which the government became the driving force for implementing educational innovations and at the same time established regulating organizations aimed at centralizing of management and standardization of education (Стрункина, 2012). So, while reforming education system trends in centralization combined with trends in autonomy establishing and education democratization.

The inspections held during 1993-1998 showed that general quality of education in primary and secondary schools of Great Britain had increased. Thus, the number of students that achieved the second level in reading and writing in KS1 was 80 percent. Results in math and reading also improved, namely, 78 and 48 percent of students of the second level in 1995 increased to 84 and subsequently 65 percent (the fourth level) in 1998. In KS3 the results were not so considerable in contrast with ones in KS4.

Thus, introduction of obligatory tests, review of national curriculum, organization of inspections, publication of league tables are aimed at enhancing the standards. Essential information for parents also plays a special role (Шмакова, 2006). Local education authorities provide parents with information about types of schools and other educational establishments, as well as about the possibility to provide children with special needs with necessary support (Education Act, 2002). In addition, they check whether the school parents chose meets these children's abilities (Education Act, 1996). While admitting to primary school a child has to do some tests aimed at defining the level of his/her abilities to plan further steps (Шмакова, 2006). 
In Great Britain acts Quality Assurance Agency (QAA). It prepares the normative documents for school inspectors to evaluate teachers' qualification, thus, ensuring the high level of the latter (Higher Education in Europe 2009: Developments in the Bolonga Process, 2009; Quality Assurance in Teacher Education in Europe; Кучай, 2014). So, at the end of XX century British system of education management was characterized by the dual process of "decentralization-centralization" that enhanced the role of government during 1970-1980. Decisions that determine trends in developing teacher education are made by government, though the essential part of the power was transferred to regional authorities.

In XXI century Department for Education established the monitoring of all teaching establishments, and the inspection of state establishments is held every 6 years, private - every three years (Delivering Results. A Strategy to 2006, 2006). New structure of inspections in XXI century demands that inspectors evaluate how curricula provide opportunities that meet students' needs and interests. The main task of secondary school modernization is the reduction of gap in achievements.

According to T. Kuchai, Great Britain (England, Wales and Scotland) and Northern Ireland have their own specificity of education. Both local education authorities and schools possess the right to decide many issues independently (Кучай, 2014). The researcher $\mathrm{N}$. Avshenyuk agrees with mentioned above. She indicates that unlike in European countries the management of education in Great Britain and Northern Ireland is characterized by considerable autonomy that is due to historical peculiarities of the country and administrative geography (see Table 1) (Стрункина, 2012).

Table 1

Organizations that Carry Out the Management of Teacher Education in Great Britain and Northern Ireland

\begin{tabular}{|c|c|c|c|}
\hline England & Wales & Scotland & Northern Ireland \\
\hline $\begin{array}{l}\text { QCA } \\
\text { (the Qualifications and } \\
\text { Curriculum Authority) }\end{array}$ & $\begin{array}{c}\text { QCAAW } \\
\text { (the Qualifications, } \\
\text { Curriculum and Assessment } \\
\text { Authority for Wales) }\end{array}$ & $\begin{array}{c}\text { LTS } \\
\text { (Learning and } \\
\text { Teaching Scotland) }\end{array}$ & $\begin{array}{l}\text { CCEA } \\
\text { (the Council } \\
\text { for Curriculum } \\
\text { Examinations } \\
\text { and Assessment) }\end{array}$ \\
\hline (National Employers' ( & $\begin{array}{l}\text { NEOST } \\
\text { rganisation for School Teachers) }\end{array}$ & $\begin{array}{c}\text { CoSLA } \\
\text { (Convention } \\
\text { of Scottish Local } \\
\text { Authorities) }\end{array}$ & $\begin{array}{c}\text { TNC } \\
\text { (Teachers' } \\
\text { Negotiating } \\
\text { Committee) }\end{array}$ \\
\hline $\begin{array}{c}\text { DfEE } \\
\text { (Department for } \\
\text { Education and } \\
\text { Employment). } \\
\text { DfES } \\
\text { (Department for } \\
\text { Education and Skills) } \\
\text { (since 2001) }\end{array}$ & $\begin{array}{c}\text { DET } \\
\text { (Department for Education } \\
\text { and Training) }\end{array}$ & $\begin{array}{c}\text { SOEID } \\
\text { (Scottish Office } \\
\text { Education and } \\
\text { Industry Department). } \\
\text { SEED } \\
\text { (Scottish Executive } \\
\text { Education Department) } \\
\text { (since 1999) }\end{array}$ & $\begin{array}{c}\text { DENI } \\
\text { (Department } \\
\text { of Education } \\
\text { Northern Ireland) }\end{array}$ \\
\hline \multicolumn{3}{|c|}{$\begin{array}{l}\text { (Disability Right Commission). } \\
\text { CRE } \\
\text { (Commission for Racial Equality). } \\
\text { EOC } \\
\text { (Equal Opportunities Commission) }\end{array}$} & $\begin{array}{c}\text { ECNI } \\
\text { (Equality Commission } \\
\text { for Northern Ireland) }\end{array}$ \\
\hline
\end{tabular}


DE GRUYTER

Порівняльна професійна педагогіка 5(4)/2015

Comparative Professional Pedagogy 5(4)/2015

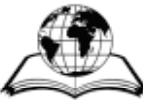

Continued

\begin{tabular}{|c|c|c|c|}
\hline England & Wales & Scotland & Northern Ireland \\
\hline $\begin{array}{l}\text { OFSTED } \\
\text { (Office for Standards } \\
\text { in Education) }\end{array}$ & $\begin{array}{c}\text { ESTYN } \\
\text { (from the Welsh language verb } \\
\text { meaning "to extend"). } \\
\text { The Education and } \\
\text { Training Inspectorate } \\
\text { for Wales } \\
\end{array}$ & $\begin{array}{l}\text { HMIE } \\
\text { (Her Majesty } \\
\text { Inspectorate } \\
\text { of Education) }\end{array}$ & $\begin{array}{c}\text { ETI } \\
\text { (Education and Training } \\
\text { Inspectorate) }\end{array}$ \\
\hline \multicolumn{2}{|c|}{$\begin{array}{c}\text { LEA } \\
\text { (Local Education Authority) }\end{array}$} & $\begin{array}{c}\text { SLA } \\
\text { (Scottish Local } \\
\text { Authority) }\end{array}$ & $\begin{array}{c}\text { ELB } \\
\text { (Education and Library } \\
\text { Board) }\end{array}$ \\
\hline $\begin{array}{c}\text { GTCE } \\
\text { (General Teaching } \\
\text { Council for England) }\end{array}$ & $\begin{array}{c}\text { GTCW } \\
\text { (General Teaching Council } \\
\text { for Wales) }\end{array}$ & $\begin{array}{l}\text { GTCS } \\
\text { (General } \\
\text { Teaching } \\
\text { Council for } \\
\text { Scotland }\end{array}$ & $\begin{array}{c}\text { GTCNI } \\
\text { (General Teaching } \\
\text { Council for Northern } \\
\text { Ireland) }\end{array}$ \\
\hline $\begin{array}{c}\text { HEFCE } \\
\text { (Higher Education } \\
\text { Funding Council } \\
\text { for England) }\end{array}$ & $\begin{array}{c}\text { HEFCW (ELWa) } \\
\text { (Higher Education Funding } \\
\text { Council for Wales) }\end{array}$ & $\begin{array}{c}\text { SHEFC } \\
\text { (Scottish Higher } \\
\text { Education } \\
\text { Funding Council) }\end{array}$ & $\begin{array}{c}\text { DENI } \\
\text { (Department of Education } \\
\text { Northern Ireland) }\end{array}$ \\
\hline \multicolumn{4}{|c|}{$\begin{array}{c}\text { NAT/UWT } \\
\text { (National Association of Teachers / Union of Women Teachers) }\end{array}$} \\
\hline \multicolumn{4}{|c|}{\begin{tabular}{c|c|c} 
NUT & & \\
(National Union of Teachers) & & \\
\end{tabular}} \\
\hline \multicolumn{4}{|c|}{$\begin{array}{c}\text { NVQs } \\
\text { (National Vocational Qualifications) }\end{array}$} \\
\hline \multicolumn{4}{|c|}{$\begin{array}{c}\text { PAT } \\
\text { (Professional Association of Teachers) }\end{array}$} \\
\hline \multicolumn{4}{|c|}{\begin{tabular}{c|c} 
PPP & \\
(Public Private Partnership) &
\end{tabular}} \\
\hline \multicolumn{2}{|c|}{$\begin{array}{c}\text { QTS } \\
\text { (Qualified Teacher Status) }\end{array}$} & $\begin{array}{c}\text { TQ } \\
\text { (Teaching } \\
\text { Qualification) }\end{array}$ & $\begin{array}{c}\text { QTS } \\
\text { (Qualified Teacher Status) }\end{array}$ \\
\hline \multicolumn{4}{|c|}{$\begin{array}{c}\text { SCITT } \\
\text { (School Centred Initial Teacher Training) }\end{array}$} \\
\hline & $\begin{array}{c}\text { UCAC } \\
\text { (Undeb Cenedlaethol } \\
\text { Athrawon Cymru) } \\
\text { (National Union of Teachers } \\
\text { of Wales) }\end{array}$ & $\begin{array}{l}\text { SSTA } \\
\text { (Scottish } \\
\text { Secondary } \\
\text { Teachers' } \\
\text { Association) }\end{array}$ & \\
\hline \multicolumn{2}{|c|}{$\begin{array}{c}\text { STRB } \\
\text { (School Teachers' Review Board) }\end{array}$} & $\begin{array}{c}\text { SNCT } \\
\text { (Scottish } \\
\text { Negotiating } \\
\text { Committee } \\
\text { for Teachers) }\end{array}$ & \\
\hline \multicolumn{2}{|c|}{$\begin{array}{c}\text { TTA } \\
\text { (Teacher Training Agency) }\end{array}$} & $\begin{array}{c}\text { SOEID } \\
\text { (Scottish Office } \\
\text { Education } \\
\text { and Industry } \\
\text { Department) }\end{array}$ & $\begin{array}{c}\text { DENI } \\
\text { (Department of Education } \\
\text { Northern Ireland) }\end{array}$ \\
\hline \multicolumn{4}{|c|}{$\begin{array}{l}\text { UCET } \\
\text { for the Education of Teachers) }\end{array}$} \\
\hline
\end{tabular}


So, the information presented in Table 1 shows what in Great Britain (England, Wales, Scotland) and Northern Ireland regional government Departments of Education are responsible for.

In England there is Department for Education and Employment (DfEE), since 2001 Department for Education and Skills (DfES); in Wales - Department of Education and Training (DET); in Scotland - Scottish Office Education and Industry Department (SOEID), since 1999 Scottish Executive Education Department (SEED); in Northern Ireland - Department of Education for Northern Ireland (DTNI).

In addition, there are other autonomous authorities such as associations, boards, councils, committees, agencies that are specialized bodies-agents engaged in indirect state control. There are regional councils for higher education funding in England, Wales, Scotland. It should be mentioned that in Northern Ireland higher education funding is carried out by the Department of Education Northern Ireland. In all regions operate special qualifications and curriculum authorities as well as commissions for equality, general teaching councils, qualified teacher status or teaching qualification.

As you can see from Table 1 systems of education management in England and Wales are quite similar. Thus, such organizations as School Teachers' Review Board, Teacher Training Agency, local education authorities have other names in Scotland and Northern Ireland, though functions are similar. At the same time such organizations as the National Association of Teachers, National Union of Teachers, National Vocational Qualifications, Professional Association of Teachers, Public Private Partnership, School Centred Initial Teacher Training operate only in England and Wales. In Scotland the inspection of educational establishments is carried out by Her Majesty Inspectorate of Education and in Northern Ireland - by Education and Training Inspectorate (Стрункина, 2015).

So, the analysis of presented information allowed to show similarities and differences in the functioning of organizations involved in the management of education in Great Britain and proved the existence of independent authorities subjected to them.

\section{CONCLUSIONS}

It has been proved that lately the democratization process in British education management has been combined with the increased attention of the state to monitoring, requirements to appropriate activity of educational establishments and trends seem to be forward education quality enhancing, democratization of evaluation, monitoring and information providing processes.

We have concluded that up to 1980 educational establishments, curricula, assessment were characterised by low autonomy and monitoring of education increased from both the local authorities and state agencies. Education quality decreased; since 1980 there was a trend in democratization of education (monitoring, evaluation, presenting information about the state of education to the public); at the end of XX century the autonomy of educational establishments in determining forms, means, learning conditions increased. There were no common national curricula or standards, but they were being developed by regional authorities. We have also presented the data that enabled to distinguish similar and different in the functioning of the organizations participating in education management in British counties and ensure the existing of independent management authorities within them.

Prospects for further researchers we consider the study of education management in other leading European countries. 


\section{REFERENCES}

1. Department for Education and Skills. (2006). Delivering Results. A Strategy to 2006. Retrieved 12.10.2015 from : http://www.ied.edu.hk/edchange/resource/english_2.html.

2. Department for Education and Skills. (2006). Five Year Strategy for Children and Learners. Retrieved 12.10.2015 from : http://planipolis.iiep.unesco.org/upload/UK/UK Dfes5yearstrategy.pdf.

3. Education, Audiovisual and Culture Executive Agency. (2009). Higher education in Europe 2009: Developments in the Bolonga Process. Retrieved 15.10.2015 from: http://www.ond. vlaanderen.be/hogeronderwijs/bologna/conference/documents/2009_Eurydice_report.pdf.

4. Eurydice European Unit. (2006). Quality Assurance in Teacher Education in Europe. Retrieved 10.10.2015 from : http://www.nefmi.gov.hu/download.php?docID=623.

5. The National Achieves. (1999). Education Act 1996. Retrieved 2.10.2015 from : http://www.legislation.gov.uk/ukpga/1996/56/pdfs/ukpga_19960056_en.pdf.

6. The National Achieves. (1997). Education Act 1997. Retrieved 2.10.2015 from : http://www.legislation.gov.uk/ukpga/1997/44/pdfs/ukpga_19970044_en.pdf.

7. The National Achieves. (2002). Education Act 2002. Retrieved 2.10.2015 from : http://www.legislation.gov.uk/ukpga/2002/32/pdfs/ukpga_20020032_en.pdf.

8. The National Achieves. (1998). School Standards and Framework Act 1998. Retrieved 25.10.2015 from : http://www.legislation.gov.uk/ukpga/1998/31/pdfs/ukpga_19980031_en.pdf.

9. The National Achieves. (1988). The Education Reform Act. Retrieved 11.10.2015 from: http://www.legislation.gov.uk/ukpga/1988/40/pdfs/ukpga_19880040_en.pdf.

10. Авшенюк, Н. (2008). Велика Британія. Енциклопедія освіти [Great Britain: Encyclopaedia of Education]. К. : Юрінком Iнтер, 1040 p. (in Ukrainian).

11. Зискин, К. (2002). Профессионально-педагогическая подготовка учителей средней школы на педагогических отделениях университетов Великобритании во второй половине XX столетия [Professional Pedagogical Training of Secondary School Teachers in Teacher Departments of British Universities in the Second Part of XX Century]. Thesis for a Candidate's Degree. Москва, 157 p. (in Russian).

12. Кучай, Т. (2014). Система професійної підготовки вчителів початкових класів до морально-етичного виховання учнів в університетах Японії [System of Primary School Teachers Professional Training for Moral and Aesthetic Education in Japanese Universities]. Черкаси : Чабаненко Ю. А., 584 p. (in Ukrainian).

13. Пуховська, Л. (1997). Професійна підготовка вчителів у Західній Свропі:спільність і розбіжності [Teacher Professional Training in Western Europe : Similarities and Differences]. К. : Вища школа, 180 p. (in Ukrainian).

14. Стрункина, Ю. (2012). Профессиональная подготовка педагогических кадров во второй половине XX века: на материалах Великобритании и России [Teacher Professional Training in the Second Part of XX Century : based on materials of Great Britain and Russian Federation]. Thesis for PhD. Ставрополь, 169 p. (in Russian).

15. Шмакова, А. (2006). Опыт развития правовых отношений 6 образовательной системе Великобритании на рубеже XX-XXI столетий [Experience in Developing Legal Relations in Education of Great Britain at the Turn of XX-XXI centuries]. Thesis for $\mathrm{PhD}$. Омск, 214 p. (in Russian). 